Jurnal Ilmu-Ilmu Peternakan 26 (1): 66 - 74

ISSN : 0852-3681

E-ISSN : 2443-0765

CFakultas Peternakan UB, http://jiip.ub.ac.id/

\title{
Pengaruh penambahan kolin klorida dalam pakan terhadap produksi, total solid, dan persistensi susu sapi perah laktasi
}

\author{
Diky Trizana, Sri Agus Bambang Santoso dan C. Budiarti Soejono
}

Fakultas Peternakan dan Pertanian Universitas Diponegoro

Jl. Drh. R. Soejono Koesoemowardojo-Tembalang, Semarang Kode Pos 50275

agusbees@gmail.com

\begin{abstract}
The study aimed to review the effects of choline chloride addition on milk production, total solid, and persistency in lactating dairy cattle. This experiment was conducted at Wahyu Agung Dairy Farm, Getasan District, Semarang Regency, Central Java. The materials used in this study were 8 lactating dairy cattle. The feed given consisted of napier grass and commercial concentrate (WA Feed) at ratio of 40:60 in dry matter (DM) base at 3.25\% BW as basal diet, and mixture of commercial choline chloride (60\%) and corncob (40\%). The experimental design used a cross-over designs with 2 treatments $\left(T_{0}\right.$ and $\left.T_{1}\right)$ and 4 replications in II periods. The treatments were feed without addition of choline chloride $\left(\mathrm{T}_{0}\right)$, and the feed with addition of choline chloride at $30 \mathrm{~g} /$ head/day $\left(T_{1}\right)$. The results showed that there was no effect of choline chloride addition in feed on dry matter intake, being 13.29 and $14.12 \mathrm{~kg} / \mathrm{head} /$ day for $\mathrm{T}_{0}$ and $\mathrm{T}_{1}$, respectively. However, milk production was significantly different $(\mathrm{P}<0.05)$ between $\mathrm{T}_{0}$ and $\mathrm{T}_{1}$, being 13.48 and $13.91 \mathrm{l} / \mathrm{head} /$ day, as well as in total solid $\left(\mathrm{T}_{0}=12.61 \%\right.$ vs $\mathrm{T}_{1}=$ $13.12 \% ; \mathrm{P}<0.05)$, eventhough there were no significant in persistency of milk $\left(\mathrm{T}_{0}=\right.$ $4.17 \%$ vs $\mathrm{T}_{1}=2.83 \%$; $\mathrm{p}>0.05$ ). The conclusions of this experiment was addition of choline chloride in feed as much as $30 \mathrm{~g} / \mathrm{head} / \mathrm{day}$ could increase milk production and total solid, but did not affect the persistency milk production.
\end{abstract}

Keywords : Choline chloride, milk production, total solid, persistency

\section{PENDAHULUAN}

Seiring dengan pertumbuhan penduduk dan ekonomi, serta semakin tingginya kesadaran masyarakat terhadap pentingnya protein hewani menyebabkan semakin tinggi pula permintaan susu oleh masyarakat dan industri pengolahan susu (IPS) di Indonesia. Namun, peternak sapi perah di Indonesia masih terkendala dalam memenuhi permintaan tersebut yang disebabkan antara lain sapi perah yang dimiliki peternak tidak mampu memproduksi susu dengan jumlah yang banyak dan kualitas yang bersaing.
Selain itu, bahan pakan selalu berubahubah dan tidak menentu komposisi pakannya, pemenuhan nutrisi sapi perah dari pakan masih dibawah standar, serta cara penanganan pasca produksi yang belum diperhatikan dengan baik.

Upaya yang dapat dilakukan untuk mengatasi masalah tersebut antara lain adalah dengan menambahkan kolin klorida dalam pakan yang belum banyak dikenal oleh peternak Indonesia. Di luar negeri, kolin klorida digunakan sebagai bahan pakan tambahan oleh peternak untuk meningkatkan produksi dan kualitas susu sapi perah. 
Kolin klorida adalah golongan vitamin, namun dapat disintesis di dalam tubuh (Anggorodi, 1994). Kolin klorida merupakan bagian dari fosfolipid esensial yang berfungsi dalam pembentukan sel, perbaikan maupun pemeliharaan sel, penyalur gerakan urat syaraf, dan andil yang terpenting dalam kualitas susu yaitu dapat meningkatkan metabolisme lemak dalam hati (Nasution dan Karyadi, 1991). Kolin merupakan nutrisi yang diperlukan bagi banyak spesies hewan karena kolin berfungsi dalam pembentukan fosfolipid untuk metabolisme lipoprotein (Xu et al., 2006). Kolin merupakan faktor lipotropik yang berperan dalam mencegah penimbunan lemak dalam hati, tetapi mempertinggi penimbunan lemak tubuh (Anggorodi, 1994). Parakkasi (1999) menjelaskan bahwa kolin berperan dalam merangsang metabolisme lemak dalam hati yaitu mencegah akumulasi lemak dalam hati dengan jalan merangsang pengangkutan dalam bentuk lecithin atau dengan jalan meningkatkan penggunaannya.

Tujuan penelitian ini adalah untuk mengkaji pengaruh penambahan kolin klorida dalam pakan terhadap produksi, total solid, dan persistensi susu sapi perah laktasi.

\section{MATERI DAN METODE}

Penelitian ini dilaksanakan pada tanggal 28 Desember 2015 - 6 Maret 2016 di peternakan sapi perah Wahyu Agung, Kecamatan Getasan, Kabupaten Semarang, Jawa Tengah. Analisis susu dilaksanakan di Balai Pelayanan Kesehatan Masyarakat Veteriner, Kabupaten Boyolali, Jawa Tengah.

\section{Materi penelitian}

Materi penelitian ini yaitu 8 ekor sapi perah betina Peranakan Friesian Holstein laktasi pada bulan laktasi ke-3 dan 4. dengan periode laktasi ke-II. Pakan yang digunakan yaitu rumput gajah dan konsentrat komersial (WA Feed) dengan rasio 40:60 dalam bahan kering berdasarkan 3,25\% bobot badan, serta campuran produk komersial kolin klorida (60\%) dan corncob (40\%). Alat yang digunakan yaitu timbangan untuk menimbang kolin klorida dengan kapasitas 5 kg dan tingkat ketelitian 1 g, timbangan pakan untuk menimbang jumlah pakan yang akan diberikan dengan kapasitas maksimal $150 \mathrm{~kg}$, kepekaan minimal $400 \mathrm{~g}$ dan dengan tingkat ketelitian 0,01 g, volumentri untuk mengukur produksi susu pagi dan sore dengan kapasitas 2 liter dengan tingkat kepekaan $50 \mathrm{ml}$, botol kaca untuk menyimpan susu yang akan diuji dan lactoscan (milkscan) untuk menganalisis kandungan nutrisi susu.

\section{Metode penelitian}

Penelitian ini dilaksanakan melalui tiga tahap, yaitu tahap persiapan, tahap perlakuan dan pengambilan data, serta tahap analisis data. Tahap persiapan yaitu melakukan adaptasi yang dilakukan selama 2 minggu meliputi pemilihan ternak berdasarkan bulan dan periode laktasi. Setelah sapi-sapi terpilih maka dilakukan pemilihan kembali berdasarkan produksi susu dan bobot badan (456,13 \pm 30,75 kg). Pada tahap ini dilakukan adaptasi pakan terhadap ternak sesuai perlakuan secara bertahap dengan tujuan agar sapi terbiasa dengan pakan perlakuan yang diberikan.

Kegiatan pada tahap perlakuan dan pengambilan data dilakukan selama 8 minggu. Perlakuan $\mathrm{T}_{0}$ yaitu pakan tanpa penambahan kolin klorida dan $\mathrm{T}_{1}$ yaitu pakan dengan penambahan kolin klorida (30 g/ekor/hari). Periode I yaitu sapi-sapi perlakuan $T_{0}$ dan $T_{1}$ yang telah beradaptasi terhadap pakan perlakuan dan dilanjutkan selama 3 minggu, 
kemudian dilakukan pengambilan data. Setelah itu, sapi-sapi perlakuan diistirahatkan yaitu tidak berikan kolin klorida selama 2 minggu. Pengistirahatan ini bertujuan untuk menghilangkan pengaruh perlakuan kolin klorida $\left(\mathrm{T}_{1}\right)$ pada sapi. Periode II yaitu sapi-sapi yang mendapatkan perlakuan $\mathrm{T}_{0}$ pada periode I diberikan perlakuan $T_{1}$, sedangkan sapi yang mendapatkan perlakuan $\mathrm{T}_{0}$ pada periode I diberikan perlakuan $\mathrm{T}_{1}$ dan pengambilan data dilakukan selama 3 minggu. Parameter yang diamati yakni

1. Konsumsi pakan, yaitu jumlah pakan yang dikonsumsi per individu dikurangi sisa pakannya setelah 24 jam.

2. Produksi susu, yaitu menjumlahkan produksi susu pada pagi dan sore hari pada saat pemerahan. Mengukur produksi susu tersebut menggunakan alat volumetri.

3. Kualitas susu, yaitu pengambilan sampel dilakukan satu kali dalam setiap minggu selama tahap perlakuan berlangsung. Pengambilan sampel dilakukan secara proporsional berdasarkan produksi susu dalam satu hari.

4. Menghitung nilai persistensi produksi susu, yaitu dengan menggunakan rumus Sudono (1983) $\begin{gathered}\text { Persistensi } \\ \text { naik }\end{gathered}=\frac{\begin{array}{c}\text { Produksi } \\ \text { susu tinggi }\end{array} \text { susu rendah }}{\begin{array}{c}\text { Produksi } \\ \text { Produksi } \\ \text { susu rendah }\end{array}} \times 100 \%$ $\begin{gathered}\text { Persistensi } \\ \text { turun }\end{gathered}=\frac{\begin{array}{c}\text { Produksi } \\ \text { susu tinggi }- \text { susu rendah }\end{array}}{\begin{array}{c}\text { Produksi } \\ \text { susu tinggi }\end{array}} \times 100 \%$

Rancangan percobaan yang digunakan yaitu Cross-over designs berdasarkan petunjuk Neter et al. (1990) dengan taraf ketelitian 5\%.

$$
\mathbf{Y}_{\mathrm{ij}(\mathrm{k})}=\mu+\alpha_{\mathrm{i}}+\beta_{\mathrm{j}}+\tau_{(\mathrm{k})}+\varepsilon_{\mathrm{ij}(\mathrm{k})}
$$

Penjelasan :

$$
\begin{aligned}
\mathrm{Y}_{\mathrm{ij}(\mathrm{k})}= & \text { nilai pengamatan pada } \\
& \text { perlakuan ke-i (perlakuan } \\
& \text { penambahan kolin klorida dan } \\
& \text { tidak) dan periode percobaan } \\
& \text { ke-j (periode I dan II) serta } \\
& \text { ternak sapi perah laktasi ke-k. } \\
= & \text { nilai rataan umum. } \\
\alpha_{\mathrm{i}}= & \text { pengaruh perlakuan ke-i } \\
& \text { (penambahan kolin klorida } \\
& \text { atau tidak). } \\
\beta_{\mathrm{j}} & \text { pengaruh periode percobaan } \\
& \text { ke-j (periode I dan II). } \\
\tau_{(\mathrm{k})}= & \text { pengaruh individu ternak sapi } \\
& \text { perah laktasi ke-k. } \\
\varepsilon_{\mathrm{ij}(\mathrm{k})=} & \text { pengaruh galat percobaan } \\
& \text { perlakuan penambahan kolin } \\
& \text { klorida atau tidak (i), periode } \\
& \text { percobaan (j) dan individu } \\
& \text { ternak sapi perah laktasi (k). }
\end{aligned}
$$

\section{HASIL DAN PEMBAHASAN}

\section{Konsumsi bahan kering}

Hasil pengamatan konsumsi bahan kering (BK) sapi perlakuan yang ditambahkan kolin klorida dan tidak ditambahkan kolin klorida dalam pakan dapat dilihat pada Tabel 1. Berdasarkan Tabel 1 terlihat bahwa konsumsi BK sapi perlakuan berkisar 11,26 - 17,25 kg BK/ekor/hari serta konsumsi BK dalam konversi persentase yaitu berkisar 2,39 - 3,40\% BB masih berada dalam kisaran normal. Sebagaimana hasil penelitian $\mathrm{Xu}$ et al. (2006) dan Mohsen et al. (2011) bahwa sapi perah laktasi mengkonsumsi pakan bersikar 14,9-16,20 kg BK/ekor/hari. Hal ini didukung oleh National Research Council (2001) bahwa konsumsi BK sapi perah yang direkomendasikan adalah 2,25-4,32\% dari bobot badan.

Konsumsi $\mathrm{BK}$ perlakuan $\mathrm{T}_{0}$ dan $\mathrm{T}_{1}$ diasumsikan bahwa pakan yang telah dikonsumsi oleh sapi-sapi perlakuan sudah memenuhi untuk kehidupan pokok dan produksi susu. Hal ini juga 
dapat diketahui bahwa dengan penambahan kolin klorida dalam pakan tidak meningkatkan palatabilitas, sehingga tidak meningkatkan konsumsi BK. Hal ini sesuai dengan penelitian $\mathrm{Xu}$ et al. (2006) bahwa penambahan kolin klorida dalam pakan tidak mempengaruhi ataupun meningkatkan konsumsi BK sapi perlakuan.

Tabel 1. Pengaruh perlakuan terhadap konsumsi BK

\begin{tabular}{ccccc}
\hline \multirow{2}{*}{ Ulangan } & \multicolumn{4}{c}{ Konsumsi bahan kering } \\
\cline { 2 - 5 } & \multicolumn{1}{c}{$\mathrm{T}_{0}$} & $\mathrm{~T}_{1}$ & $\mathrm{~T}_{0}$ & $\mathrm{~T}_{1}$ \\
\hline & -------- kg/ekor/hari------- & --- BB & --------- \\
2 & 15,37 & 16,51 & 3,39 & 3,38 \\
3 & 10,65 & 17,25 & 2,39 & 3,44 \\
4 & 12,88 & 12,27 & 3,19 & 2,81 \\
5 & 11,46 & 15,20 & 2,43 & 3,39 \\
6 & 16,46 & 13,20 & 3,37 & 2,91 \\
7 & 14,01 & 11,42 & 2,79 & 2,57 \\
8 & 11,26 & 13,72 & 2,58 & 3,40 \\
Total & 14,20 & 13,39 & 3,17 & 2,84 \\
\hline Rata-rata & $13,29 \pm 2,08$ & $14,12 \pm 2,03$ & $2,91 \pm 0,42$ & $3,09 \pm 0,35$ \\
\hline
\end{tabular}

Berdasarkan uji statistik yang telah dilakukan bahwa konsumsi BK sapi-sapi perlakuan pada Tabel 1 menunjukan tidak terdapat perbedaan yang nyata antara $T_{0}$ dan $T_{1}$. Hal ini dipertegas bahwa pemberian kolin klorida pada sapi perah laktasi tidak memberikan pengaruh baik itu penurunan konsumsi BK maupun peningkatan konsumsi BK. Hal ini sesuai dengan pendapat Mohsen et al. (2011) yang menyatakan bahwa pemberian kolin klorida tidak signifikan terhadap total konsumsi pakan. Hal ini diperkuat oleh pendapat Piepenbrink and Overton (2003) serta Guretzky et al. (2006) bahwa pemberian kolin klorida pada sapi perah tidak mempengaruhi konsumsi bahan kering.

Berdasarkan komposisi ransum penelitian yang digunakan, kandungan PK (13,22\%) dan TDN (67,78\%) masih tergolong normal. Hal ini sesuai dengan pendapat Chiba (2009) bahwa produktivitas sapi perah dapat optimal apabila dibutuhkan PK sebesar 12-16\% dan TDN 68\% dari BK pakan. Adhani dkk. (2012) menambahkan bahwa konsumsi pakan yang ditentukan dari kadar nutrisi pakannya dapat memenuhi kebutuhan hidup pokok maupun produksi.

\section{Pengaruh perlakuan terhadap produksi susu \\ Hasil pengamatan perlakuan} tanpa penambahan kolin klorida dan perlakuan penambahan kolin klorida dalam pakan terhadap tampilan produksi susu dapat dilihat pada Tabel 2. Pada Tabel 2 terlihat bahwa tampilan produksi susu sapi perah laktasi pada perlakuan $T_{0}$ dan $T_{1}$ masih tergolong normal yang berkisar 10,51-19,68 liter/ekor/hari. Hal ini sesuai dengan pendapat Utomo dan Miranti (2010) bahwa rata-rata produksi susu sapi perah yang ada di Indonesia sekitar 10 liter/ekor/hari.

Berdasarkan hasil analisis ragam terlihat bahwa rata-rata produksi susu perlakuan $T_{1}$ menunjukkan hasil yang lebih banyak baik dalam satuan volume (liter) maupun dalam satuan bobot (kg) 
$(\mathrm{p}<0,05)$ daripada perlakuan $\mathrm{T}_{0}$. Hal ini mengindikasikan bahwa dengan penambahan kolin klorida sebanyak 30 g/ekor/hari dalam pakan sapi perah laktasi mampu meningkatkan pemeliharaan dan perbaikan struktur membran sel termasuk sel-sel sekretori. Sel-sel sektretori merupakan sel yang berfungsi dalam sintesis susu selama sapi perah laktasi. Oleh karena itu, semakin cepat terpacunya perbaikan selsel sekretori maka sintesis susu yang dilakukan berlangsung optimal. Hal ini sesuai dengan The National Academies (1998) bahwa kolin klorida berperan penting dalam pembentukan sel, pemeliharaan sel serta perbaikan keutuhan struktur membran sel.

Tabel 2. Pengaruh perlakuan terhadap produksi susu

\begin{tabular}{ccccc}
\hline \multirow{2}{*}{ Ulangan } & \multicolumn{2}{c}{ Produksi susu } & \multicolumn{2}{c}{ Produksi susu } \\
\cline { 2 - 5 } & \multicolumn{2}{c}{$\mathrm{T}_{0}$} & $\mathrm{~T}_{1}$ & \multicolumn{2}{c}{$\mathrm{T}_{0}$} & $\mathrm{~T}_{1}$ \\
\hline & ----- liter/ekor/hari----- & --- kg/ekor/hari----- \\
2 & 15,20 & 15,10 & 15,63 & 15,52 \\
3 & 11,85 & 11,69 & 12,16 & 12,04 \\
4 & 12,47 & 15,12 & 12,82 & 15,55 \\
5 & 12,86 & 19,68 & 13,22 & 20,23 \\
6 & 12,90 & 14,43 & 13,22 & 14,80 \\
7 & 10,51 & 11,76 & 10,78 & 12,06 \\
8 & 13,89 & 11,82 & 14,24 & 12,13 \\
\hline Total & 18,18 & 11,66 & 18,65 & 11,95 \\
\hline Rata-rata & $13,48 \pm 2,35^{\text {a }}$ & $13,91 \pm 2,81^{b}$ & $13,84 \pm 2,41^{\text {a }}$ & $14,29 \pm 2,90^{\mathrm{b}}$ \\
\hline Keterangan & $:{ }^{\text {a, b }}$ Superskrip dengan huruf kecil berbeda pada baris yang sama dengan \\
& satuan yang sama menunjukan perbedaan yang nyata (p<0,05).
\end{tabular}

Peningkatan produksi susu ini juga diduga karena kolin klorida mampu meningkatkan VFA (Volatile Fatty Acid). VFA terdiri dari asam asetat, asam propionat, dan asam butirat yang merupakan bahan baku dan sumber energi dalam sintesis susu. Oleh karena itu, semakin meningkatnya produksi VFA maka semakin meningkat pula bahan baku dan ketersediaan energi untuk sintesis susu. Hal ini sesuai dengan pendapat Parakkasi (1999) bahwa dengan pemberian kolin sebanyak $500 \mathrm{mg} / \mathrm{kg}$ pakan dapat meningkatkan total bakteri rumen, produksi gas dan VFA.

Hasil penelitian ini sesuai dengan pendapat $\mathrm{Xu}$ et al. (2006) yang menyatakan bahwa dengan pemberian kolin klorida pada sapi sebanyak 30 $\mathrm{g} /$ hari dapat meningkatkan produksi susu menjadi 29,5 kg/hari dibandingkan pakan tanpa penambahan kolin klorida yaitu 25,4 kg/hari. Mohsen et al. (2011) menambahkan bahwa peningkatan produksi susu dengan pemberian kolin klorida dimungkinkan karena salah satu atau lebih dari alasan berikut yaitu kecernaan nutrisi yang lebih tinggi, pemberian kolin klorida meningkatkan produksi susu dengan cara meningkatkan lipid dari metabolisme hati. Selain alasan tersebut, kolin klorida berkontribusi dalam pencegahan terhadap gangguan metabolisme seperti metabolisme lipid yang abnormal.

\section{Pengaruh perlakuan terhadap total solid (TS)}

Tampilan TS susu hasil pengamatan yang diperoleh dari perlakuan tanpa penambahan kolin 
klorida dalam pakan $\left(\mathrm{T}_{0}\right)$ dan perlakuan

( $\left.\mathrm{T}_{1}\right)$ dapat dilihat pada Tabel 3. penambahan kolin klorida dalam pakan

Tabel 3. Pengaruh perlakuan terhadap tampilan total solid

\begin{tabular}{ccccc}
\hline \multirow{2}{*}{ Ulangan } & \multicolumn{2}{c}{ Total solid } & \multicolumn{2}{c}{ Total solid } \\
\cline { 2 - 5 } & \multicolumn{1}{c}{$\mathrm{T}_{0}$} & $\mathrm{~T}_{1}$ & $\mathrm{~T}_{0}$ & $\mathrm{~T}_{1}$ \\
\hline 1 & $-----\% /$ ekor/hari----- & ---- kg/ekor/hari----- \\
2 & 13,69 & 13,88 & 2,14 & 2,16 \\
3 & 12,88 & 13,74 & 1,57 & 1,65 \\
4 & 13,58 & 13,66 & 1,74 & 2,12 \\
5 & 12,71 & 14,06 & 1,68 & 2,83 \\
6 & 11,74 & 12,25 & 1,55 & 1,81 \\
7 & 12,37 & 12,72 & 1,33 & 1,54 \\
8 & 11,74 & 12,71 & 1,67 & 1,54 \\
\hline Total & 12,15 & 11,92 & 2,27 & 1,43 \\
\hline Rata-rata & $12,61 \pm 0,75^{\mathrm{a}}$ & $13,12 \pm 0,82^{\mathrm{b}}$ & $1,74 \pm 0,31^{\mathrm{a}}$ & $1,89 \pm 0,47^{\mathrm{b}}$ \\
\hline
\end{tabular}

Keterangan : ${ }^{\mathrm{a}, \mathrm{b}}$ Superskrip dengan huruf kecil berbeda pada baris yang sama dengan satuan yang sama menunjukan terdapat perbedaan yang nyata $(\mathrm{p}<0,05)$.

Hasil pengamatan dari perlakuan $\mathrm{T}_{0}$ dan $\mathrm{T}_{1}$ terhadap tampilan total solid susu sapi perah perlakuan masih tergolong normal berkisar 11,7414,06\%. Berdasarkan hal ini dapat diketahui bahwa penambahan kolin klorida dalam pakan sebanyak 30 g/ekor/hari tidak memberikan efek negatif terhadap total solid susu yang dihasilkan oleh sapi perlakuan $\mathrm{T}_{1}$. Hal ini sesuai dengan pendapat Hermawan dkk. (2003) bahwa kandungan total solid susu sapi perah berkisar 11-18\%.

Hasil analisis ragam pada Tabel 3 menunjukkan bahwa perlakuan $\mathrm{T}_{1}$ menghasilkan TS lebih besar secara nyata $(\mathrm{p}<0,05)$ dibandingkan dengan $\mathrm{T}_{0}$. Lebih tingginya perlakuan $T_{1}$ tersebut diduga karena kolin klorida dapat meningkatkan metabolisme lemak dalam hati dan membentuk fosfolipid sebagai metabolisme lipoprotein, dalam hal ini lipoprotein diangkut dalam plasma darah menuju sel sekretori yang digunakan sebagai prekursor pembentukan lemak susu. Oleh karena itu, meningkatnya lemak susu juga akan meningkatkan kandungan TS dalam susu. Hal ini sesuai hasil penelitian $\mathrm{Xu}$ et al. (2006) bahwa kolin sebagai donor metil dan berfungsi dalam pembentukan fosfolipid untuk metabolisme lipoprotein. Hal tersebut mengidikasikan bahwa pemberian kolin klorida sebesar 30 g/ekor/hari pada sapi perah laktasi mampu merangsang laju metabolisme lemak dalam hati, sehingga mampu meningkatkan TS susu. Hasil penelitian ini sesuai dengan Piepenbrink dan Overton (2003) serta Guretzky (2006) bahwa pakan yang ditambahkan kolin klorida dapat meningkatkan lemak susu, total solid, dan produksi susu sapi perah laktasi.

Hasil penelitian Mohsen et al. (2011) menunjukkan bahwa kolin klorida secara signifikan meningkatkan lemak susu dan total solid susu. Dilaporkan lebih lanjut bahwa pemberian kolin klorida pada sapi perah laktasi sebanyak 30 g/ekor/hari berpengaruh terhadap lemak susu, baru kemudian protein, laktosa, dan total solid. 
Pengaruh perlakuan terhadap
persistensi produksi susu

Tampilan persistensi produksi susu perlakuan tanpa penambahan kolin klorida dalam pakan $\left(\mathrm{T}_{0}\right)$ dan perlakuan penambahan kolin klorida dalam pakan $\left(\mathrm{T}_{1}\right)$ dapat dilihat pada Tabel 4.

Tabel 4. Pengaruh perlakuan terhadap persistensi produksi susu

\begin{tabular}{|c|c|c|c|c|c|c|}
\hline \multirow{3}{*}{ Ulangan } & \multicolumn{3}{|c|}{$\mathrm{T}_{0}$} & \multicolumn{3}{|c|}{$\mathrm{T}_{1}$} \\
\hline & \multicolumn{2}{|c|}{$\begin{array}{l}\text { Pengamatan } \\
\text { minggu ke- }\end{array}$} & \multirow[t]{2}{*}{ Rataan } & \multicolumn{2}{|c|}{$\begin{array}{l}\text { Pengamatan } \\
\text { minggu ke- }\end{array}$} & \multirow[t]{2}{*}{ Rataan } \\
\hline & $1-2$ & $2-3$ & & $1-2$ & $2-3$ & \\
\hline & \multicolumn{3}{|c|}{-------------\%\%------------- } & \multicolumn{3}{|c|}{-------------\%\%------------- } \\
\hline 1 & 1,12 & 3,34 & 1,11 & 0,39 & 0,00 & 0,19 \\
\hline 2 & 3,61 & 1,28 & 2,44 & 4,35 & 4,29 & 4,32 \\
\hline 3 & 6,20 & 5,00 & 5,60 & 4,60 & 0,20 & 2,40 \\
\hline 4 & 8,71 & 2,78 & 5,75 & 7,45 & 3,85 & 5,65 \\
\hline 5 & 7,26 & 10,74 & 9,00 & 5,02 & 0,00 & 2,51 \\
\hline 6 & 2,90 & 0,47 & 1,22 & 4,33 & 2,99 & 3,66 \\
\hline 7 & 3,27 & 4,09 & 3,68 & 4,94 & 1,90 & 1,52 \\
\hline 8 & 10,28 & 1,15 & 4,57 & 4,33 & 0,43 & 2,38 \\
\hline Total & 43,36 & 28,85 & 33,37 & 35,41 & 13,67 & 22,63 \\
\hline Rata-rata & 4,69 & 2,49 & $4,17 \pm 2,66$ & 4,43 & 1,24 & $2,83 \pm 1,69$ \\
\hline
\end{tabular}

Pada Tabel 4 terlihat bahwa penurunan produksi susu yang terjadi terhadap kedua perlakuan masih tergolong normal, dengan rataan persentase penurunan produksi susu $\mathrm{T}_{0}$ yaitu $4,17 \%$ dan $\mathrm{T}_{1}$ yaitu $2,83 \%$. Hal ini sesuai dengan Church (1988) bahwa penurunan produksi susu yaitu sekitar 5$7 \%$ pada sebagian besar sapi perah. Hal ini didukung oleh Blakely dan Bade
(1994) bahwa penurunan produksi susu setelah mencapai puncaknya tersebut diperkirakan besarnya 6\% tiap bulannya. Hasil analisis ragam pada rata-rata persistensi susu antara $T_{0}$ dan $T_{1}$ yaitu tidak terdapat perbedaan yang nyata.

Persistensi susu mingggu ke-1-2 dan 2-3 juga ditampilkan pada Gambar 1 yang disajikan dalam bentuk diagram garis.

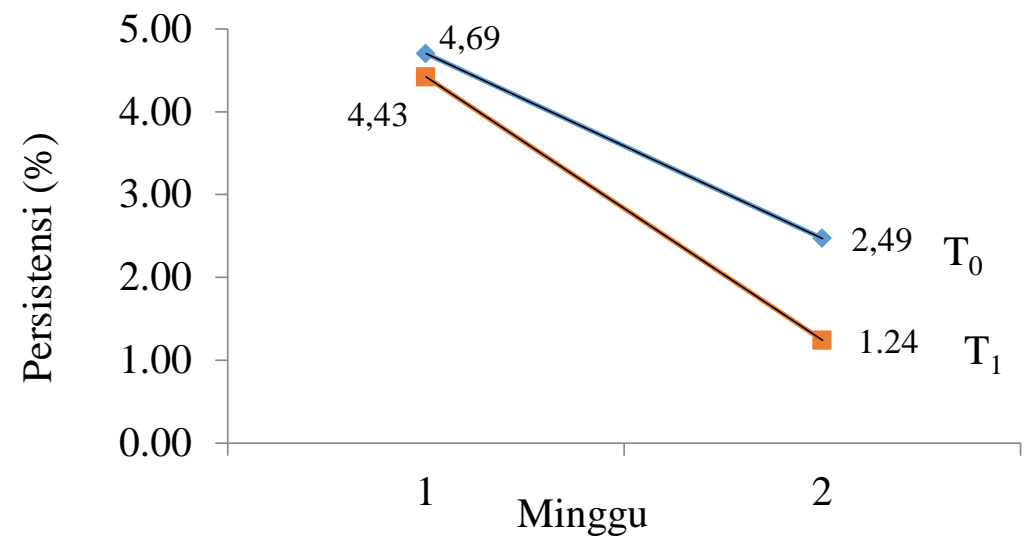

Gambar 1. Kurva persistensi susu antara pengamatan minggu ke- 1-2 dan 2-3

Gambar 1 menunjukkan bahwa persentase perlakuan $T_{0}$ dan $T_{1}$ mengalami penurunan yang cenderung sama, artinya perlakuan dengan 
penambahan kolin klorida dalam pakan sapi perah laktasi tidak mempengaruhi nilai persentase penurunan produksi susu. Hal ini dapat diketahui bahwa dengan penambahan kolin klorida sebanyak 30 g/ekor/hari dalam pakan sapi perah laktasi tidak memberikan pengaruh terhadap persistensi, baik itu penurunan produksi susu secara perlahan maupun penurunan produksi secara drastis. Persistensi susu sangat dipengaruhi oleh produksi susu yang dihasilkan seekor sapi perah selama laktasi, dan hal ini juga sangat berkaitan dengan faktor genetik dari sapi perah tersebut. Sebagaimana dijelaskan oleh Anggraeni (2000) bahwa kemampuan produksi susu sapi perah dipengaruhi oleh faktor genetik, lingkungan dan interaksi antar keduanya.

\section{KESIMPULAN}

Hasil penelitian ini menyimpulkan bahwa penambahan kolin klorida dalam pakan sebanyak 30 g/ekor/hari untuk sapi perah laktasi mampu meningkatkan produksi susu, serta total solid susu.

\section{DAFTAR PUSTAKA}

Adhani, N. D. A. C., T. Nurhajati dan A. T. S. Estoepangestie. 2012. Potensi pemberian formula pakan konsentrat komersial terhadap konsumsi dan kadar bahan kering tanpa lemak susu. Agroveteriner. 1(1): 11-16

Anggorodi, R. 1994. Ilmu makanan ternak umum. PT. Gramedia Pustaka Utama, Jakarta.

Anggraeni, A. 2000. Keragaan produksi susu sapi perah: Kajian pada faktor koreksi pengaruh lingkungan internal. Wartazoa. 9(2): 41-49

Blakely, J. dan D. H. Bade. 1994. Ilmu peternakan. Gajah Mada University Press, Yogyakarta.
(Diterjemahkan oleh Srigando, B. dan Soedarsono).

Chiba, L. I. 2009. Animal nutrition handbook. $\quad 2^{\text {nd }} \quad$ Revision. Department of Animal Sciences. Auburn University. Alabama.

Church, D. C. 1988. The ruminant animal digestive physiology and nutrition a reston book. Prentice Hall. Engle Wood Cliffs, New Jersey.

Guretzky, N., A. Janovick, D. B. Carlson, J. E. Garrett dan J. K. Drackley. 2006. Lipid metabolite profile and milk production for Holstein and Jersey cows fed rumen-protected choline during the periparturient period. J. Dairy Sci. 89(1): 188200.

Hermawan., H. Suprtaman, R. Tawaf dan B. Kusbiantoro. 2003. Perbaikan metode pemerahan dan mutu konsentrat dalam upaya peningkatan kualitas dan kuantitas produksi susu sapi perah. Laporan Hasil Pengkajian Balai Pengkajian Teknologi Pertanian (BPTP) Jawa Bawat.

Mohsen, M. K., M. H. A. Gaafar, M. M. Khalafalla, A. A. Shitta dan A. M. Yousif. 2011. Effect of rumen protected choline supplementation on digestibility, rumen activity and milk yield in lactating Friesian cows. Slovak. J. Anim. Sci. 44(1): 13-20.

Nasution, A. H. dan D. Karyadi. 1991. Pengetahuan gizi mutakhir "Vitamin". PT. Gramedia Pustaka Utama, Jakarta.

National Research Council. 2001. Nutrient requirement of dairy cattle. Seventh Revised Edition. National Academic Press, Washington DC.

Neter, J. A., W. Wasserman dan M. H. Kutner. 1990. Applied linear 
statistical models. Third edition. Irwin, Homewood, Illinois.

Parakkasi, A. 1999. Nutrisi dan makanan ternak ruminan. Universitas Indonesia Press, Jakarta.

Piepenbrink, M. S. and T. R. Overton. 2003. Liver metabolism and production of cows fed increasing amounts of rumenprotected choline during the periparturient period. J. Dairy Sci. 86(5): 1722-1733.

Sudono, A. 1983. Pedoman beternak sapi perah. Direktorat Bina Produksi Peternakan. Direktorat Jendral Peternakan, Deptan, Jakarta.

The National Academies. 1998. Dietary reference intakes for thiamin, riboflavin, niacin, vitamin b6, folate, vitamin b12, pantothenic acid, biotin and choline. National Academy Press, Washington D.C.

Utomo, B. dan D. P. Miranti. 2010. Tampilan produksi susu sapi perah yang mendapat perbaikan manajemen pemeliharaan. Caraka Tani. 25(1): 21-25

$\mathrm{Xu}$, Guo Zhong., Ye Jun'An, Liu Jian Xin dan Yu Yue Ying. 2006. Effect of rumen-protected choline addition on milk performance and blood metabolic in trasition dairy cows. J. Anim. Sci. 19(3): 390395. 